\title{
Randomised, double blind, placebo controlled trial of inosine pranobex in rheumatoid arthritis
}

\author{
Maciej Brzeski, Rajan Madhok, John A Hunter, Hilary A Capell
}

\begin{abstract}
In a randomised, placebo controlled, double blind study inosine pranobex was assessed as a possible second line drug in rheumatoid arthritis. Twenty four patients received inosine pranobex ( $3 \mathrm{~g} /$ day) and 26 patients received placebo for up to 24 weeks. Morning stiffness, articular index, grip strength, pain score, erythrocyte sedimentation rate, $C$ reactive protein, IgG, IgM, and serum urate were assessed at weeks 0,12 , and 24 . Baseline characteristics were similar except for a significantly higher $C$ reactive protein in the placebo group. No significant improvement occurred in any variable: $(a)$ when comparing week 0 with week 12 or week 24 for either group, (b) comparing active drug with placebo at week 12 or 24 , or (c) taking all 50 patients as one group. Withdrawal from the study for lack of response or side effects was similar in both groups. Serum urate increased transiently but significantly with inosine pranobex (a recognised side effect). It is concluded that inosine pranobex has no second line activity in rheumatoid arthritis. Further, $\mathbf{5 0}$ patients effectively given placebo showed no spontaneous improvement in their disease activity.
\end{abstract}

Inosine pranobex is a synthetic immunomodulating drug. ${ }^{1}$ It is the $p$-acetamidobenzoic acid salt of the $N N$-dimethylamino-2-propanol: inosine complex in a 3:1 molar ratio, and is also known as isoprinosine, inosiplex, and methisoprinol. It increases interleukin 2 production by lymphocytes, ${ }^{2}$ stimulates $\mathrm{T}$ cell differentiation, ${ }^{3}$ and induces lymphocyte surface markers. ${ }^{3}$ Inosine pranobex has been used in various viral illnesses ${ }^{4}$-for example, it speeds recovery from herpes simplex infections 5 and may prolong survival in subacute sclerosing panencephalitis, ${ }^{6}$ a disorder of some interest given current speculation about a potential viral aetiology for rheumatoid arthritis (RA).

A previous small open study of inosine pranobex in RA suggested possible second line effect with reduction in erythrocyte sedimentation rate (ESR) and fibrinogen in some patients as well as improved morning stiffness and functional grade. ${ }^{7}$ In this study we report on the efficacy and toxicity of inosine pranobex in RA.

Inosine pranobex is well tolerated, the only important side effect being a transient rise in serum urate due to metabolism of the inosine component. Acute gout has not been reported.

Patients and methods

Patients had definite or classical RA not adequately controlled with analgesics and non- steroidal anti-inflammatory drugs. Subjects were aged 20-65 years with at least one of the following: early morning stiffness longer than 45 minutes, ESR $>25 \mathrm{~mm} / \mathrm{h}$, or Ritchie articular index $>12$. Exclusion criteria were current or likely pregnancy and breast feeding; current or recent (within three months) use of other immunomodulating or second line drugs or systemic corticosteroids; severe renal impairment, hyperuricaemia, or previous gout.

\section{STUDY DESIGN}

Fifty patients were randomly allocated to receive active drug or placebo in a double blind study over 24 weeks. Ethical committee approval was obtained. At weeks 0, 12, and 24 the following assessments were made: visual analogue pain score (100 mm horizontal line), early morning stiffness, grip strength (mean of three measurements with cuff inflated to $20 \mathrm{mmHg}$ at start), Ritchie articular index, ESR (Westergren), C reactive protein, IgG, IgM, and serum urate. Patients were specifically asked about adverse events. The same metrologist assessed the patients at the same time of day (morning) at each visit. The patients' usual non-steroidal anti-inflammatory drugs remained unchanged during the study, and simple analgesia was allowed. Withdrawal from the study required assessment by a consultant.

DOSE

Inosine pranobex was given as $1 \mathrm{~g}$ thrice daily.

\section{STATISTICS}

Mann-Whitney two tailed, signed ranks tests, and Wilcoxon matched pairs.

\section{Results}

Twenty four patients were assigned to active drug and 26 to placebo. Table 1 shows their baseline characteristics. The only significant difference between the groups was a higher $\mathrm{C}$ reactive protein in the placebo group $(p=0.02)$.

\section{TOXICITY}

Eleven of 24 patients treated with inosine pranobex withdrew before the end of the study as did 14 of 26 placebo treated patients. Table 2 shows the reasons for withdrawal and the adverse effects not severe enough to lead to withdrawal. Overall in the inosine pranobex group serum urate concentrations rose significantly at week 12 (median $240 \mu \mathrm{mol} / \mathrm{l}$ at week 0 , 
$320 \mu \mathrm{mol} / \mathrm{l}$ at week $12, \mathrm{p}=0.001$ ) but were falling by week 24 (median $295 \mu \mathrm{mol} / 1, \mathrm{p}=0.025$ compared with week 0 ) (table 3 ). The slight rise in the placebo group was not significant (table 3). In six patients taking inosine pranobex serum urate rose well above normal (mean week

Table 1: Baseline characteristics of active and placebo treatment groups. Except where indicated by ${ }^{*}$ figures are medians (interquartile ranges in brackets)

\begin{tabular}{|c|c|c|}
\hline & $\begin{array}{l}\text { Placebo } \\
(n=26)\end{array}$ & $\begin{array}{l}\text { Inosine pranobex } \\
(n=24)\end{array}$ \\
\hline $\begin{array}{l}\text { Men/women* } \\
\text { Age (years) } \\
\text { RA>5 years* (n) } \\
\text { Seropositive } \\
\text { ARA } \ddagger \text { class II/III }\end{array}$ & $\begin{array}{l}5 / 21 \\
56 \cdot 8 \\
18 \\
15 \\
20 / 6\end{array}$ & $\begin{array}{l}4 / 20 \\
59 \cdot 3 \\
20 \\
17 \\
20 / 4\end{array}$ \\
\hline $\begin{array}{l}\text { Alł } \\
\text { EMS } \neq \text { (h) } \\
\text { Right grip (mmHg) } \\
\text { Left grip (mmHg) } \\
\text { Pain score } \\
\quad(100 \mathrm{~mm} \text { scale) }\end{array}$ & $\begin{array}{l}13(7-20) \\
2 \cdot 0(1 \cdot 0-3 \cdot 0) \\
78(58-95) \\
74(56-86) \\
57(40-78)\end{array}$ & $\begin{array}{l}14 \cdot 5(6 \cdot 3-19) \\
2 \cdot 0(1 \cdot 0-3 \cdot 0) \\
71(59-118) \\
68(56-106) \\
57(43-69)\end{array}$ \\
\hline $\begin{array}{l}\text { ESR }(\mathrm{mm} / \mathrm{h}) \\
\text { CRP }(\mathrm{mg} / \mathbf{l}) \\
\mathrm{IgG}(\mathrm{g} / \mathrm{l}) \\
\mathrm{IgM}(\mathrm{g} / \mathrm{l}) \\
\text { Urate }(\mu \mathrm{mol} / \mathrm{l})\end{array}$ & $\begin{array}{l}55(21-82) \\
36(17-60) \dagger \\
12 \cdot 8(10 \cdot 1-17 \cdot 1) \\
1 \cdot 5(0 \cdot 9-1 \cdot 7) \\
270(230-310)\end{array}$ & $\begin{array}{l}35(19-63) \\
13(10-23) \\
12 \cdot 7(10 \cdot 8-14 \cdot 0) \\
1 \cdot 4(0 \cdot 9-2 \cdot 0) \\
240(210-300)\end{array}$ \\
\hline
\end{tabular}

Table 2: Reason for withdrawal from study in each group

\begin{tabular}{|c|c|c|}
\hline & $\begin{array}{l}\text { Inosine } \\
\text { pranobex } \\
(n=24)\end{array}$ & $\begin{array}{l}\text { Placebo } \\
(n=26)\end{array}$ \\
\hline $\begin{array}{l}\text { Withdrawal: } \\
\text { Lack of effect } \\
\text { Gastrointestinal } \\
\text { Rash/mouth ulcers } \\
\text { Miscellaneous* }\end{array}$ & $\begin{array}{l}4 \\
4 \\
3 \\
0\end{array}$ & $\begin{array}{l}4 \\
4 \\
2 \\
4\end{array}$ \\
\hline Total & 11 & 14 \\
\hline $\begin{array}{l}\text { Adverse events } \\
\text { (continued study) } \\
\text { Gastrointestinal } \\
\text { Itch/rash } \\
\text { Dry mouth } \\
\text { Other } \\
\text { Hyperuricaemia }\end{array}$ & $\begin{array}{l}2 \\
1 \\
0 \\
2 \\
6\end{array}$ & $\begin{array}{r}4 \\
4 \\
1 \\
0\end{array}$ \\
\hline Total & 11 & 9 \\
\hline
\end{tabular}

${ }^{*}$ Miscellaneous included insomnia (one patient), unexplained crying (one), anaemia (one), and intercurrent medical illness (one).
0 was $350 \mu \mathrm{mol} / \mathrm{l}$, at week 12 it was $515 \mu \mathrm{mol} / \mathrm{l}$, normal up to $420 \mu \mathrm{mol} / \mathrm{l})$. Three of these patients continued the study and three were withdrawn at week 12 for other reasons. Although the highest serum urate recorded was $630 \mu \mathrm{mol} / \mathrm{l}$, no patient developed gout.

\section{EFFICACY}

There was no significant improvement in any variable at weeks 12 or 24 for either treatment group compared with week 0 , nor was there any statistically significant improvement when comparing inosine pranobex with placebo at weeks 12 or 24 . The only changes showed deterioration in disease activity at week 12-that is, increase in ESR and pain score on treatment with inosine pranobex, increase in IgG and decrease in left grip strength with placebo (table 3 ). By week 24 these changes were no longer significant as patients deteriorating clinically were withdrawn from the study.

\section{Discussion}

Our study with 50 patients showed that there is no beneficial effect of inosine pranobex in RA when used in a dose of $3 \mathrm{~g} /$ day for up to 24 weeks. Sixteen per cent of patients withdrew for lack of effect. The few statistically significant differences detected showed deterioration of disease activity, whether comparing patients at weeks 12 or 24 with week 0 in active treatment or placebo groups separately, or comparing active treatment with placebo at weeks 12 or 24 . As expected, serum urate increased significantly in the active treatment group (owing to metabolism of inosine), though acute gout did not occur. This increase was transient and is biochemical confirmation of compliance. The drug was well tolerated, with a comparable incidence of adverse events in both active and placebo groups.

Two previous, smaller open studies suggested that inosine pranobex was an effective treatment for RA and might have disease modifying properties. ${ }^{78}$ Response in both studies was seen within eight weeks. In one study nine of 15 patients treated with $3 \mathrm{~g} /$ day inosine pranobex

Table 3: Results with inosine pranobex and placebo at 0, 12, and 24 weeks. Figures show median values

\begin{tabular}{|c|c|c|c|c|c|c|}
\hline & \multicolumn{3}{|c|}{ Inosine pranobex } & \multicolumn{3}{|c|}{ Placebo } \\
\hline & 0 & 12 & 24 & 0 & 12 & 24 \\
\hline $\begin{array}{l}\text { AI* } \\
\text { EMS (h) } \\
\text { Right grip (mmHg) } \\
\text { Left grip (mmHg) }\end{array}$ & $\begin{array}{l}14 \cdot 5 \\
2 \cdot 0 \\
71 \\
68\end{array}$ & $\begin{array}{l}12 \\
3 \cdot 0 \\
70 \\
75\end{array}$ & $\begin{array}{l}8 \\
2 \cdot 0 \\
72 \\
75\end{array}$ & $\begin{array}{l}13 \\
2 \cdot 0 \\
78 \\
74\end{array}$ & \multirow[t]{2}{*}{$\begin{array}{l}11 \\
3 \cdot 0 \\
78 \\
64 \\
(\mathrm{p}=0 \cdot 01) \\
65\end{array}$} & \multirow[t]{2}{*}{$\begin{array}{l}5 \\
1 \cdot 0 \\
80 \\
80 \\
(p=0 \cdot 48) \\
37\end{array}$} \\
\hline Pain score (100 mm scale) & 57 & $\begin{array}{l}64 \\
(p=0.026)\end{array}$ & $\begin{array}{l}59 \\
(p=0 \cdot 70)\end{array}$ & 57 & & \\
\hline $\operatorname{ESR}(\mathbf{m m} / \mathbf{h})$ & 35 & \multirow{2}{*}{$\begin{array}{l}43 \\
(p=0.02) \\
21 \\
12.6\end{array}$} & \multirow{2}{*}{$\begin{array}{l}34 \\
(\mathrm{p}=0 \cdot 80) \\
23 \\
12 \cdot 9\end{array}$} & 55 & 57 & 49 \\
\hline $\begin{array}{l}\text { CRP (mg/l) } \\
\operatorname{IgG}(\mathbf{g} / \mathbf{l})\end{array}$ & $\begin{array}{l}13 \\
12 \cdot 7\end{array}$ & & & $\begin{array}{l}36 \\
12 \cdot 8\end{array}$ & \multirow{2}{*}{$\begin{array}{l}34 \\
15 \cdot 7 \\
(p=0 \cdot 008) \\
1 \cdot 45 \\
283\end{array}$} & \multirow{2}{*}{$\begin{array}{l}26 \\
12 \cdot 4 \\
(p=0 \cdot 75) \\
1 \cdot 4 \\
300\end{array}$} \\
\hline $\begin{array}{l}\operatorname{IgM}(g / l) \\
\text { Urate }(\mu \mathrm{mol} / \mathrm{l})\end{array}$ & $\begin{array}{l}1 \cdot 4 \\
240\end{array}$ & $\begin{array}{l}1 \cdot 2 \\
320 \\
(p=0.001)\end{array}$ & $\begin{array}{l}1 \cdot 1 \\
295 \\
(p=0.025)\end{array}$ & $\begin{array}{l}1 \cdot 5 \\
270\end{array}$ & & \\
\hline
\end{tabular}

Values not significant unless stated.

${ }^{*}$ For abbreviations see table 1 . 
improved with reduction of early morning stiffness, joint circumference, ESR, and fibrinogen. ${ }^{7}$ Close inspection of the data shows that changes in these indices were often too small to be clinically meaningful, and only three out of 15 could truly be said to have benefited. A German study used a complex protocol with intravenous corticosteroids for some patients, and many were receiving oral corticosteroids as well. ${ }^{8}$ As rheumatologists have few minimally toxic drugs the suggestion of possible benefit warranted further investigation of inosine pranobex.

Although originally labelled an antiviral drug, inosine pranobex is more correctly designated an immunomodulating agent. ${ }^{1}$ It is used against a variety of viral diseases, including herpes simplex $^{5}$ influenza (where it partially restores the immunosuppression associated with infection), ${ }^{9}$ and subacute sclerosing panencephalitis. ${ }^{6}$ Given early in infectious mononucleosis inosine pranobex produces no worthwhile clinical benefit as shown in a detailed but unpublished paper (Gillett). A small study showed that inosine pranobex augmented proliferation of B cells containing Epstein-Barr virus nuclear material, both from patients with infectious mononucleosis and those with RA. ${ }^{10}$ Inosine pranobex also increases interleukin 2 production by lymphocytes in vitro. ${ }^{2}$ Whether one would theoretically expect these effects to be beneficial in RA is debatable, though it is worth noting that cyclosporin $A$ reduces interleukin 2 production. Perhaps inosine pranobex should be given earlier in the disease, when any aetiological agent might still be present.

When all 50 patients are taken as a group, effectively though unintentionally given placebo, it is clear that active RA of this severity does not show spontaneous remission. This contrasts with a recent study in the United States, where the placebo group showed considerable improvement. ${ }^{11}$ Whether or not the use of systemic corticosteroids is relevant is unclear, but one has long suspected that patients receiv- ing prednisolone surreptitiously consume larger doses than prescribed. Such compliance is difficult to test, and we know of no convincing evidence to either confirm or refute this clinical hunch. Two points emerge: (a) masterly pharmacological inactivity is inappropriate in active RA, (b) perhaps we should question the use of a placebo limb in therapeutic trials in RA if corticosteroids are avoided and reasonable numbers recruited.

We are indebted to Sister A Thomson, our metrologist, Miss A Tierney for typing the manuscript, and Edwin Burgess Ltd for supplying inosine pranobex and placebo.

1 Ginsberg T, Hadden J W. Immunopharmacology of methisoprinol. In: Fudenberg $\mathrm{H} \mathrm{H}$, Whitten $\mathrm{H} \mathrm{D}$, Ambrogi F, eds. Immunomodulation: new frontiers and advances. New York: Plenum Press, 1984: 331-48. (Proceedings of a symposium on recent advances on immunomodulators, 14-16 May 1982, Italy.)

2 Nakamura T, Miyasaka N, Pope R M, Talal N, Russell I J. Immunomodulation by isoprinosine: effects on in vitro immune functions of lymphocytes from humans with autoimmune diseases. Clin Exp Immunol 1983; 52: 67-74.

3 Wybran J, Appelboom T. Isoprinosine (inosiplex): immunological and clinical effects. In: Fudenberg $\mathrm{H} \mathbf{H}$, Whitten $\mathbf{H}$ D, Ambrogi F, eds. Immunomodulation: new frontiers and
advances. New York: Plenum Press, 1984: 363-74. (Proceedings of a symposium on recent advances on immunomodulators, 14-16 May 1982, Italy.)

4 Galli M, Lazzarin A, Moroni M, Zanussi C. Treatment of recurrent viral infectious diseases by methisoprinol. In: Fudenberg H H, Whitten H D, Ambrogi F, eds. Immunomodulation: new frontiers and advances. New York: Plenum Press, 1984: 385-97. (Proceedings of a symposium on recent advances on immunomodulators, 14-16 May 1982, Italy.)

5 Galli M, Lazzarin A, Moroni M, Zanussi C. Inosiplex in recurrent herpes simplex infections. Lancet 1982; ii: 331-2.

6 Jones C E, Dyken P R, Huttenlocher P R, Jabbour J T, ones C E, Dyken P R, Huttenlocher P R, Jabbour J T,
Maxwell $\mathrm{K} \mathrm{W}$. Inosiplex therapy in subacute sclerosing Maxwell K W. Inosiplex therapy in sube

7 Wybran J, Famaey J P, Appleboom T. Inosiplex: A novel treatment in rheumatoid arthritis? $\mathcal{f}$ Rheumatol 1981; 8: 643-6.

8 Becker H, Loers E, Helmke K, Federlin K. The treatment of rheumatic diseases with inosiplex: clinical and immunomodulating effects of inosiplex in rheumatic diseases. Immun Infekt 1986; 3: 93-9.

9 Hadden J W, Hadden E M, Coffey R G. Isoprinosine augmentation of phytohaemagglutinin induced lymphocyte proliferation. Infect Immun 1976; 3: 382-7.

10 Becker $\mathrm{H}$, Helmke $\mathrm{K}$. Inosiplex enhances the growth of Epstein-Barr nuclear antigen-positive B-cells from patients Epstein-Barr nuclear antigen-positive B-cells from patients with rheumatoid arthritis and infectious

11 Williams H J, Ward J R, Dahl S L, et al. A controlled trial comparing sulphasalazine, gold sodium thiomalate, and placebo in rheumatoid arthritis. Arthritis Rhewm 1988; 31: 702-13. 